\title{
Indexing and Environmental Risk of Allergenic Protein Subunits of Egyptian Pollens
}

\author{
Abd El-Moneim M.R. AFIFY* \\ Cairo University, Faculty of Agriculture, Department of Biochemistry, B.o. Box 12613, Gamma st, Giza, Cairo, Egypt; \\ abdelmoneimafify@yahoo.com (*correspondingauthor)
}

\begin{abstract}
Four Egyptian pollen pellets: sunflower, clover, maize and broad beans, were evaluated for environmental risk of allergenic protein subunits, indexing amino acids, as well as nucleic acids contents. Protein fractions were subsequently extracted as albumin, globulin, urea and SDS-soluble proteins, by different methods. The results showed that albumin and globulin fractions represent the major constituents in different pollen pellets and amounted $33.24-40.3 \%$ and $32.57-37.22 \%$ respectively. SDS soluble protein showed minor amount. The electrophoretic separation of albumin and globulin extracts of sunflower pollen showed the presence of 8 protein subunits, which varied in their molecular weight between 4-67 KiloDalton (KDa); allergic protein subunits with MW 35 and 45 $\mathrm{KDa}$ were identified in all pollen pellets tested. Indexing and general analysis of the four pollen pellets showed that carbohydrates ranged from 28.12 (maize) to 36.12 (sunflower), while total chlorophyll ranged from 5.85 (broad bean) to 6.07 (maize) mg/100 g fresh weight. It is also clear that the protein content of pollen pellets is above $40 \%$ and therefore they could be considered as a protein rich source. Broad bean pellets had the highest amount of protein content (48.31\%). The lipid content ranged from 4.47 to $15.7 \%$, according to pollen source. All pollen pellets contained relatively high quantities of RNA, which are nearly three times the equivalent of DNA content. Relative values of total free amino acids of four pollens were considerably low (below 20\%) and ranged from $2.93 \pm$ 0.089 (sunflower) to $15.99 \pm 0.015 \mu \mathrm{mol} / \mathrm{mg}$ fw (broad beans).
\end{abstract}

Keywords: amino acids, carbohydrates, electrophoretic proteins, nucleic acids

\section{Introduction}

Pee natural pollen is rich in carbohydrates, proteins, amino acids, vitamins and minerals, and therefore considered a good nutrition supplement, as well as proper for medicinal treatments, as reported by Carpes et al. (2009).

Honey containing pollen from plants is known to be poisonous or toxic and unsafe for human consumption (Afify, 2010). Pollen analysis helps to identify such types of honey, and can also protect the consumer against any possible allergic reactions to specific pollen, to certain sensitive people. Further reliable information about important plants responsible for pollen quality is obtained by analysis of the kinds and quantities of pollen in the atmosphere. Honey is one of the best suppliers of energy and necessary substances in human's nutrition all over the world (Carpes et al., 2009). There are some protein bands which had been identified by SDS polyacrylamide gel electrophoresis and ranged from low $14.40 \mathrm{KDa}$, up to 116 $\mathrm{KDa}$ molecular weight (Nazarian et al., 2010). Honey compounds, in addition to sugars, are lipids and minerals. Relative quantity of the proteins in honey compound is considered as a quality index. Determination of the quantity of plant origin (pollen) and animal origin (honey bee) of the proteins of honey is an important, yet unknown, aspect.
Knowing this ratio can be an important index for quality control of honey (Nazarian et al., 2010). Pollen pellets collected from honey bees for aging at 62 floral species were analysed for protein and amino acid content, and their value for honey bee nutrition was determined. The crude protein levels of all pollen pellets analysed ranged from $9.2 \%$ for Hypochoeris radicata (flat weed) to $37.4 \%$ for Echium plantagineum (Paterson's curse), with a mean of $25.9 \%$ (Somerville and Nicol, 2006).

Pollen has high content of polyphenol substances, chiefly flavonoids with antioxidant and antimicrobial activity (Basim et al., 2006). The study of phenolic compounds has increased greatly, mainly due to the antioxidant capacity of these substances in scavenging free radicals that are harmful to human health (Afify et al., 2011; Afify et al., 2012). In vitro trials have demonstrated that some flavonoids have greater antioxidant activity than vitamins E and C (Almaraz-Abarca et al., 2007; Rice-Evans et al., 1996).

The present investigation aimed to analyse four types of Egyptian pollen pellets for free amino acid and nucleic acids, as well as electrophoretic separation of different protein fractions by polyacrylamide gel electrophoresis (SDSPAGE). Different proteins were extracted as albumin, globulin, urea soluble proteins and SDS soluble protein, and examined by SDS-PAGE. Evaluating for environmental risk 
144

of allergenic protein subunits found in pollen pellets will help using protein as a significant factor for indexing honey bees.

\section{Materials and methods}

\section{Sampling}

Four types of pollen pellets (five samples each) were collected from Faculty of Agriculture (Fayoum) by honey bees. The plant sources of pollen pellets were identified by microscopic examination (Hyde and Adams, 1958). Fresh pollen pellets were placed in containers and stored in the deep freezer for chemical analysis. Pollen pellet sources used for investigation were: 1. Sunflower (Helianthus annus, Composite); 2. Egyptian clover (Trifolium alexandrinum, Leguminosae); 3. Maize (Zea mays, Gramineae). 4. Broad bean (Vicia faba, Leguminosae).

\section{General chemical analysis}

Ash, fat and protein were determined as described in AOAC (1975). Total carbohydrate and reducing sugars were determined according to Asatoor and King (1954). Total soluble sugars were determined using the phenolsulphuric method of Dubois et al. (1956). Total chlorophyll and carotenoids were determined according to Holden (1965) and Urbach et al. (1976). Pigments were isolated by extraction in $80 \%$ acetone and then quantitatively determined by the method of Holden (1965) and Urbach et al. (1976). Compounds' content was calculated using the following equations:

(1) $\mathrm{C} a=12.7 \times \mathrm{E} 663-2.69 \times \mathrm{E} 645$

(2) $\mathrm{C} b=22.9 \times \mathrm{E} 645-4.68 \times \mathrm{E} 663$

(3) $\mathrm{C} a+b=20.2 \times \mathrm{E} 645+8.02 \times \mathrm{E} 663$

(4) $\mathrm{C} c=4.75 \times \mathrm{E} 542.5-0.226 \times \mathrm{E} a+b$

where $\mathrm{C} a, \mathrm{C} b, \mathrm{C} a+b$ and $\mathrm{C} c$ means the content $(\mathrm{mg} / \mathrm{g}$ $\mathrm{fw}$ ) of chlorophyll $a$, chlorophyll $b$, the sum of chlorophylls $a$ and $b$, and carotenoids, respectively; $\mathrm{fw}=$ fresh weight.

\section{Total free amino acid analysis}

The total free amino acid content of the pollen was quantified using ninhydrin reagent, according to Sadasivam and Manickam (1996). $2 \mathrm{ml}$ of extract, $2 \mathrm{ml}$ of buffered ninhydrin reagent $[0.8 \mathrm{~g}$ of ninhydrin, $0.12 \mathrm{~g}$ of hydrindantin in $30 \mathrm{ml}$ of methyl cellusolve and $10 \mathrm{ml}$ of acetate buffer $(\mathrm{pH} 5.5)]$ were added and the mixture was heated on a boiling water bath for $15 \mathrm{~min}$. The solution was then cooled to room temperature and $3 \mathrm{ml}$ of $50 \%$ ethanol were added. The extinction of the purple color developed was read at $570 \mathrm{~nm}$ after $10 \mathrm{~min}$, using a spectrophotometer. Appropriate blanks were set up and the color equivalence of the amino acids was compared. A calibrated solution of glycine was used as standard.

\section{Extraction and determination of DNA and RNA}

DNA and RNA were extracted according to Nieman and Poulsen (1962): (1) Nucleic acid extraction recommendations and determination as follows: the pollen pellets were suspended in $5 \mathrm{ml}$ of $0.3 \mathrm{~N} \mathrm{NaOH}$ and held at $30{ }^{\circ} \mathrm{C}$ for 18 hours. The sediment was removed by centrifugation and washed once with $5 \mathrm{ml}$ of $0.3 \mathrm{~N} \mathrm{NaOH}$. The supernatant equals the RNA fraction.

The DNA-protein sediment was resuspended in $2 \mathrm{ml}$ water, followed by the addition of $2 \mathrm{ml}$ of $1 \mathrm{~N}$ perchloric acid. The DNA-protein sediment was suspended in $3 \mathrm{ml}$ of $0.5 \mathrm{~N}$ percholric acid, heated at $70{ }^{\circ} \mathrm{C}$ for 15 minutes, and centrifuged at $2{ }^{\circ} \mathrm{C}$. The supernatant equals the DNA fraction.

(2) Nucleic acid estimation: the absorbance of the nucleic acid extracts was measured at 250,260,265, 280 and $310 \mathrm{~nm}$. Samples and control were dissolved in $0.3 \mathrm{~N}$ $\mathrm{NaOH}$ and considered unidentified. Calculation of RNA was carried out in the presence of 0.04 or $0.2 \mathrm{~N}$ percholric acid $=0.346$, while for DNA $0.5 \mathrm{~N}$ percholric acid $=0.290$ was used.

\section{Protein extraction}

Fresh pollen samples were defatted with cold pure acetone $(1: 1 \mathrm{w} / \mathrm{v})$. The defatted samples were subsequently extracted as described by Afify and Ghali (1987) with four solutions, as follows: 1) Water with $0.02 \% \mathrm{Na}$ azide (albumin); 2) Tris-borate $0.125 \mathrm{M}$ buffer, $\mathrm{pH} 8.9$ (globulin); 3) Tris-borate 0.125 buffer, $\mathrm{pH} 8.9$ with $\mathrm{M}$ (urea); 4) Tris-borate 0.125 buffer, $\mathrm{pH} 8.9$ with SDS-ME 2 $\%$

\section{Protein determination}

Protein contents were determined in protein extracts according to the methods of Bradford (1976) using Coomassie Brilliant Blue G-250 dye, which binds with protein to form a complex that absorbs visible light of 595 $\mathrm{nm}$. Protein was determined in SDS-ME extract according to the De Wreed and Stegmann (1981) method: protein solution, containing 0.5 to $5.0 \mathrm{mg}$ of protein, with a volume of 50-500 $\mu$; water was added and completed to $0.5 \mathrm{ml}$, and $0.5 \mathrm{ml}$ of propanol 2-ol and $0.5 \mathrm{ml}$ of alkaline $\mathrm{H}_{2} \mathrm{O}_{2}$ mixed; the solution was left at room temperature for $10 \mathrm{~min} ; 0.5 \mathrm{ml}$ of Biuret reagent was added and mixed; the new solutions were again left at room temperature for $30 \mathrm{~min}$, subsequently measurements were done at the absorbance of $550 \mathrm{~nm}$. Bovine serum albumin was used as standard.

\section{Preparation of samples for SDS-PAGE}

Samples were boiled for $3 \mathrm{~min}$ with 4\% SDS and 2\% ME ( $v / v$ ) giving a final concentration of $2 \%$ SDS and $1 \%$ ME, according to Afify and Ghali (1987).

\section{Electrophoresis}

SDS-PAGE 5\% and $15 \%$ polyacrylamide (PAA) was carried out according to Laemmli (1970) in Tris-glycine buffer $\mathrm{pH} 8.3$ with $0.1 \%$ SDS. Protein bands were stained with Coomassie Brilliant Blue R 250 (0.1\%) in 10\% acetic acid and 20\% methanol. Gels were distained in 10\% acetic acid and 20\% methanol. Electrophoresis was carried out in vertical electrophoresis chamber unit with cooling system.

\section{Statistical analysis}

Data were subjected to an analysis of variance and the means were compared using the Least Significant Difference (LSD) test, at the 0.05 level, as recommended by Snedecor and Cochran (1956). 


\section{Results and discussion}

\section{General Chemical Analysis}

The results in Tab. 1 showed that pollen pellets had total carbohydrates ranged from 28.12 (maize) to 36.12 $\mathrm{g} / 100 \mathrm{~g}$ fresh weight (sunflower); and total chlorophyll ranged from 5.85 (broad bean) to $6.07 \mathrm{mg} / 100 \mathrm{~g}$ fresh weight (maize). The pollen pellets of sunflower were characterized by having high amounts of carbohydrates (total soluble reducing and non-reducing sugars), total chlorophyll and carotenoids, while the pollen pellets of maize contained the highest value of fat $(15.79 \%)$ and chlorophyll $b$ (3.72 mg/100g fresh weight). On the other hand, pollen pellets of broad bean contained the lowest amounts of total chlorophyll $(5.85 \mathrm{mg} / 100 \mathrm{~g}$ fresh weight) and carotenoids (1.91 mg $/ 100 \mathrm{~g}$ fresh weight) when compared with the other pollen types. It was found that the pollen pellets of sunflower were relatively rich in carotenoid and could be utilized as carotenoids-rich source, since it was well known that carotenoids were considered as provitamins. Broad bean pellets had the highest amount of protein content, $48.31 \%$. The lipid content ranged from $4.47 \%$ up to $15.7 \%$ according to pollen source. Low levels of total soluble and reducing sugars for pollen pellets of maize were observed. Higher protein contents, over 40\%, were found in all four types of Egyptian pollen pellets, which were in agreement with the high protein content of $25.9 \%$ in bee pollen, produced in the Southeast of Australia (Somerville and Nicol, 2006). The greatest part of nitrogen content in pollen was in the protein fraction, this being the second most abundant group of nutrients, after the carbohydrates. Therefore, proteins of pollen pellets were fractionated and investigated for their ratio. As stated by Somerville and Nicol (2006), the crude protein levels, of all pollen pellets analysed, ranged from 9.2\% (Hypochoeris radicata) to $37.4 \%$ (Echium plantagineum), with a mean of $25.9 \%$. Therefore, honey proteins could be used as chemical markers of the floral origin of honey (Baroni et al., 2002) or for higher levels of valuable minerals (Stanciu et al., 2011). The results were in agreement with Carpes et al. (2009) who described that protein and reducing sugars were $20.47 \%$ and $48 \%$, respectively, noted on different pollen types.

Based on the results upon the high protein content $(40.02 \pm 0.27$ to $48.31 \pm 0.43 \%)$, reducing sugars (9.77 to 20.87 ) and lipid content ( 4.47 to $15.79 \%$ ) it can be affirmed that pollen could be an excellent food supplement (Tab. 1).
The lipid content of pollen pellets was similar to that found in Hypochoeris radicata pollen, in the Southeast of Australia (11.2\%). The high content of reducing sugars in pollen could be justified by the presence of honey or nectar in the fluid that cements the pollen grains (Stanley and Linkens, 1974).

\section{Nucleic acids content of pollen}

Results in Tab. 2 revealed that the content of RNA and DNA markedly varied according to pollen source, since each pollen type had its specific protein pattern, as previously discussed. It was clear that all pollen pellets varieties contain relatively high quantities of RNA, which were nearly three times equivalent to the content of DNA. A positive relation between total extracted protein and total nucleic acids was observed. For instance, pollen pellets of broad bean, which contained the highest amount of protein $(48.31 \pm 0.43 \%)$, were characterized also by a high level of total nucleic acids $(168.91 \mathrm{mg} / \mathrm{g} \mathrm{fw})$. Nucleic acids content was considered an important factor in developing hybrid plants, for its favourable influence upon pollen tube elongation and gene expression, which can help identify previously unknown genes. All these should be valuable focus points for further study of pollen's development and function (Rubinelli et al., 1998).

\section{Total free amino acids}

Relative values of free amino acids from the four Egyptian pollen types were considerably low (below 20\%) and ranged between $2.93 \pm 0.089$ (sunflower) and $15.99 \pm$ $0.015 \mu \mathrm{mol} / \mathrm{mg} \mathrm{fw}$ (broad beans) (Tab. 2). Sunflower, however, showed an extremely low level of total free amino acid content, constituting just $2.93 \pm 0.089 \mu \mathrm{mol} / \mathrm{mg} \mathrm{fw}$ of the pollen. Broad beans contain the highest level of free amino acids $(15.99 \pm 0.015)$, followed by maize and Egyptian clover $(9.73 \pm 0.045)$ (Tab. 2). All four pollen pellets showed a relatively high amount of free amino acids in comparison to other, angiosperm families studied (Mondal et al., 2009). Proline was present as a major amino acid in the pollen of almost all investigated taxa (Pfahler and Linskens, 1970), while alanine, amino-n-butyric acid, aspartic acid, glutamic acid, methionine, phenylalanine and others represented different predominant forms. Considerable amount of homology was observed in the amino acid composition of the same family's plants, the homology being more pronounced within plants belonging to the same genus. Thus, it can be concluded that the study

Tab. 1. General analysis of four types of pollen pellets

\begin{tabular}{ccccc}
\hline \multirow{2}{*}{ Constituents $(\%)$} & \multicolumn{4}{c}{ Pollen pellets sources } \\
\cline { 2 - 5 } & Sunflower & Egyptian clover & Maize & Broad beans \\
\hline Crude protein & $40.78 \pm 2.12$ & $43.42 \pm 1.87$ & $40.02 \pm 1.93$ & $48.31 \pm 2.01$ \\
\hline Crude fat & $4.86 \pm 0.01$ & $4.47 \pm 0.02$ & $15.79 \pm 0.009$ & $10.09 \pm 0.03$ \\
\hline Total carbohydrate & $36.12 \pm 0.87$ & $34.32 \pm 0.98$ & $28.12 \pm 0.68$ & $33.56 \pm 0.99$ \\
\hline Total soluble sugar & $22.97 \pm 0.02$ & $22.45 \pm 0.03$ & $10.80 \pm 0.01$ & $20.28 \pm 0.02$ \\
\hline Reducing sugar & $20.87 \pm 0.11$ & $20.55 \pm 0.21$ & $9.77 \pm 0.23$ & $19.18 \pm 0.08$ \\
\hline Non reducing sugar & $2.10 \pm 0.01$ & $1.90 \pm 0.02$ & $1.03 \pm 0.01$ & $1.30 \pm 0.01$ \\
\hline Chlorophyll a* & $4.25 \pm 0.04$ & $3.48 \pm 0.03$ & $2.35 \pm 0.04$ & $2.30 \pm 0.02$ \\
\hline Chlorophyll b* & $3.33 \pm 0.01$ & $3.09 \pm 0.03$ & $3.72 \pm 0.02$ & $3.55 \pm 0.02$ \\
\hline Total Chlorophyll* & $7.58 \pm 0.98$ & $6.57 \pm 0.78$ & $6.07 \pm 0.56$ & $5.85 \pm 0.47$ \\
\hline Carotenoids* & $9.76 \pm 0.12$ & $2.11 \pm 0.42$ & $8.26 \pm 0.65$ & $1.91 \pm 0.22$ \\
\hline Note: $^{*}$ mg $/ 100 \mathrm{gfw}$ & & & &
\end{tabular}

Note: *mg /100g fw 
146

of such biochemical characters has laid the foundation for further research on the genetically diverse groups of organisms, which has exemplified a more definitive approach than morphological observation when dealing with similar species or families. Thus, free amino acids of pollen pellets can be used as molecular markers.

\section{Protein contents of different fractions of pollen}

Quantity of pollen proteins of honey have been less considered as an index of quality control of honey. Therefore, studying protein bands by electrophoresis, as well as searching for allergenic protein subunits, is very important for indexing pollen pellets. The protein content of different extracted fractions, i.e. albumin, globulin, urea soluble proteins and SDSME soluble protein are presented in Tab. 3 and Fig. 1. The results showed that albumin and globulin fractions represented the major constituents in different studied pollen pellets, amounting $33.24-40.3 \%$ and $32.57-37.22 \%$ respectively. SDS soluble protein showed minor amount and ranged between 5.96-9.83\%. Total extracted protein reached its maximum value $(24.13 \mathrm{~g} / 100 \mathrm{~g})$ at broad bean, since globulin fraction represents its highest value $(27.22 \%)$ of the total extracted protein, while the total extracted protein reached its minimum value $(19.53 \mathrm{~g} / 100 \mathrm{~g})$ in pollen pellets of maize, which also had the maximum percentage of albumin $(40.3 \%)$ in comparison with the other pollen pellet types. The ratios of albumin to globulin were generally the same in the four studied pollen pellet varieties. Crude protein level of pollen pellets collected by honey bees from different plants were variable and ranged from $8-40 \%$ or $9.2-37.4 \%$ (Herbert, 1992).

As a general overview, it was apparent that the aforementioned data indicated that different pollen pellets, under study, contained relatively moderate amounts of protein, carbohydrates, fat, pigments and minerals. It could be suggested that pollen grains of each specific crop could be collected during every season, in suitable quantities, in order to study their chemical composition, as well as for the preparation of aqueous sterilized extracts, according to a standard technique. The extracts could later be used in some clinical purposes. Furthermore, with the help of pollen pellets' chemical analysis assemblages can be made correlating with previous studies (Carpes et al., 2009). On the other hand, the results revealed that lipid and protein constituents, taken as a group, may provide a key for the identification of pollen pellet sources.

\section{Electrophoretic separation of po Ilen pellets proteins}

The protein profile of the pollen pellets of four major plants sources has been developed. Separation of the protein patterns with polyacrylamide gel electrophoresis was carried out in order to identify the differences between the four types of pollen and to analyse the allergic protein subunits. The proteins were extracted consequently with

Tab. 2. Nucleic acid and free amino acids content of four types of pollen pellets ( $\mathrm{mg} / 100 \mathrm{gm}$ fresh weight)

\begin{tabular}{cccccc}
\hline Pollen source & RNA & DNA & $\begin{array}{c}\text { Total } \\
\text { nucleic acids }\end{array}$ & $\begin{array}{c}\text { Total free amino } \\
\text { acids }(\mu \mathrm{mol} / \mathrm{mg} \mathrm{fw})\end{array}$ & $\begin{array}{c}\text { Total protein } \\
\mathrm{N} \mathrm{x} \mathrm{6.25}\end{array}$ \\
\hline Sunflower & $34.47 \pm 0.76$ & $11.34 \pm 0.12$ & $45.81 \pm 0.35$ & $2.93 \pm 0.089$ & $40.78 \pm 0.23$ \\
Egyptian clover & $86.48 \pm 0.59$ & $28.4 \pm 0.23$ & $114.90 \pm 0.10$ & $9.73 \pm 0.045$ & $43.42 \pm 0.22$ \\
Maize & $27.53 \pm \mathrm{O} .64$ & $9.73 \pm 0.47$ & $37.26 \pm 0.13$ & $9.73 \pm 0.045$ & $40.02 \pm 0.27$ \\
Broad bean & $133.10 \pm 0.51$ & $35.81 \pm 0.76$ & $168.91 \pm 1.73$ & $15.99 \pm 0.015$ & $48.31 \pm 0.43$ \\
\hline
\end{tabular}

Note: All values are significantly different from control at $\mathrm{p} \geq 0.05$. Mean value of total free amino acid content $(\mu \mathrm{mol} / \mathrm{mg} \mathrm{fw})$

Tab. 3. Percentage of protein fraction of four pollen pellets

\begin{tabular}{ccccccccc}
\hline \multirow{2}{*}{ Protein fractions } & \multicolumn{7}{c}{ Pollen pellets sources } \\
\cline { 2 - 9 } & Sunflower & $\%$ & Egyptian clover & $\%$ & Maize & $\%$ & Broad beans & $\%$ \\
\hline Albumin(water soluble) & $6.93 \pm 0.13$ & 33.24 & $8.32 \pm 0.12$ & 35.36 & $7.87 \pm 0.12$ & 40.3 & $8.23 \pm 0.13$ & 34.11 \\
Globulin (Buffer soluble) & $6.93 \pm 0.13$ & 33.24 & $8.42 \pm 0.10$ & 35.78 & $6.36 \pm 0.16$ & 32.57 & $8.98 \pm 0.12$ & 37.22 \\
Urea soluble protein & $5.08 \pm 0.13$ & 24.37 & $5.45 \pm 0.05$ & 23.16 & $3.38 \pm 0.01$ & 17.31 & $5.40 \pm 0.14$ & 22.38 \\
SDS Soluble protein & $1.91 \pm 0.01$ & 9.16 & $1.34 \pm 0.01$ & 5.69 & $1.92 \pm 0.06$ & 9.83 & $1.52 \pm 0.01$ & 6.29 \\
Total protein fractions & $20.85 \pm 0.23$ & 100 & $23.53 \pm 0.32$ & 100 & $19.53 \pm 0.27$ & 100 & $24.13 \pm 0.23$ & 100
\end{tabular}

Note: $\%$ Percentage $=$ percentage of protein fraction related total soluble protein

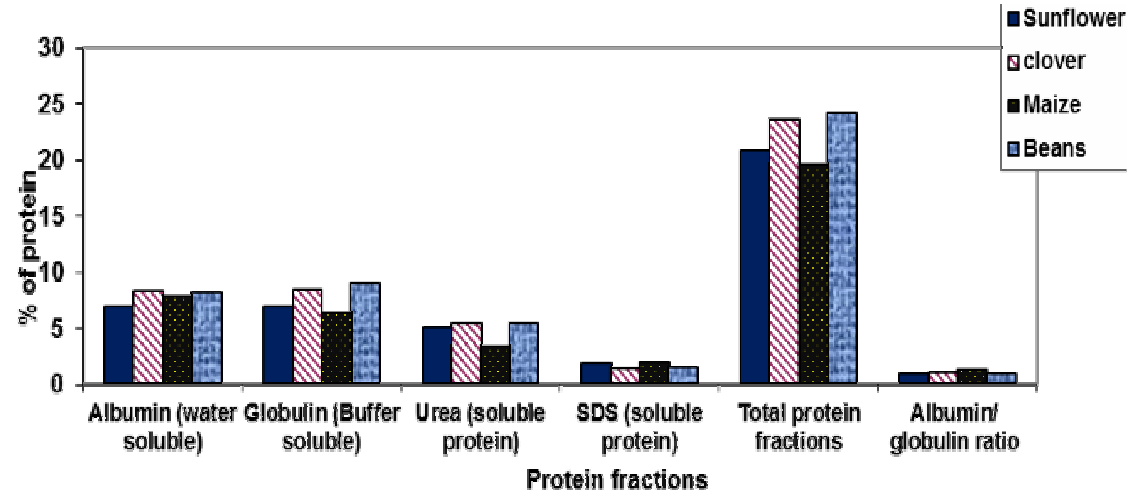

Fig. 1. Relative percentage of protein fractions of four pollen pellets 
water (albumin), Tris-borate and buffer (globulin), as shown in Fig. 2.

Water extraction was more efficient to extract most of protein subunits (albumin fraction). The rest of un-extracted protein was extracted with Tris-borate buffer (globulin fraction). The cross linked proteins were dissociated to the native molecular weights by using Tris borate buffer with $5 \mathrm{M}$ urea and SDS-ME 2\%. The amount of these cross-linked proteins represented $24.37 \%$ and $9.16 \%$ from the total soluble protein, as shown in Tab. 1.

The electrophoretic separation of water and buffer extracts of sunflower pollen showed the presence of 8 protein subunits, which varied in their molecular weight between 67 and $4 \mathrm{KDa}$. The molecular weights in sunflower pollen were identified as $67,53,55,52,43,32,28$ and $4 \mathrm{KDa}$. Water and buffer extracts of Egyptian clover pollen revealed the presence of 10 subunits, with molecular weights of $70,67,60,56,5 \mathrm{I}, 50,43,42,39$ and $16 \mathrm{KDa}$, while maize pollen contains four protein subunits, with molecular weights of $51,39,35$ and $4 \mathrm{KDa}$. On the same time, broad bean pollen showed the presence of seven protein subunits with molecular weights of $70,67,64,56,51,43$ and $15 \mathrm{KDa}$ (Fig. 2).

From these results the protein structure of Egyptian clove and broad bean pollens seems to be close to each other. As it is well known, each plant family has its specific protein profile; on this basis, an unknown pollen pellets source could be identified and related to a specific family, according to its protein profile.

The water extract was found to induce a highly proteasome activity, showing interesting antioxidant properties (Graikou $e t$ al., 2011). As stated by Nazarian et al. (2010), the molecular weight of pollen protein expanded from low $14.40 \mathrm{KDa}$ to high $116 \mathrm{KDa}$. Our results are in agreement with Porter (1981), who stated that SDS gel separates the soluble protein of pollen maize, and represented 17 major bands ranging in size from 80.000 to less than $12.400 \mathrm{KDa}$. The soluble proteins (albumin and globulin) were high in protein content, with more than $60 \%$ of the total soluble protein. A new major protein, with an approximate molecular weight of about 35 $\mathrm{KDa}$ was detected in two varieties (C. arizonica var. 'arizonica' and $C$. arizonica var. 'glabra'). Immuno-blotting using the serum of a cypress allergic subject, showed that the protein with $35 \mathrm{KDa}$ was also the major allergen of both varieties in pollen extracts, and it approved the presence of this protein in maize pollen (Shahali et al., 2007). On the other hand, protein with $45 \mathrm{KDa}$ has been reported as the most representative protein in pollen extracts of Mediterranean countries.

Our results proved the presence of this protein with 45 $\mathrm{KDa}$ in sunflower, Egyptian clove and broad beans, while it is absent from maize pollen (Shahali et al., 2007). The insoluble protein fraction was treated with urea or SDS and subjected to electrophoresis, but suffered high interference from the presence of large amounts of starch and polysaccharides, and so it is not shown. The insoluble protein (urea and SDS soluble protein) were low in protein content, with less than $40 \%$ of the total soluble protein. The soluble protein patterns differ not only qualitatively, but quantitatively also. Three major low molecular weight bands of the soluble proteins represent 28$30 \%$ of the total soluble fraction (Porter, 1981), while those bands comprise only $5-6 \%$ of proteins; this result lead to the conclusion that they represent different compartments of the pollen grain. Specifically, the urea and SDS soluble proteins are well bounded and the soluble proteins are

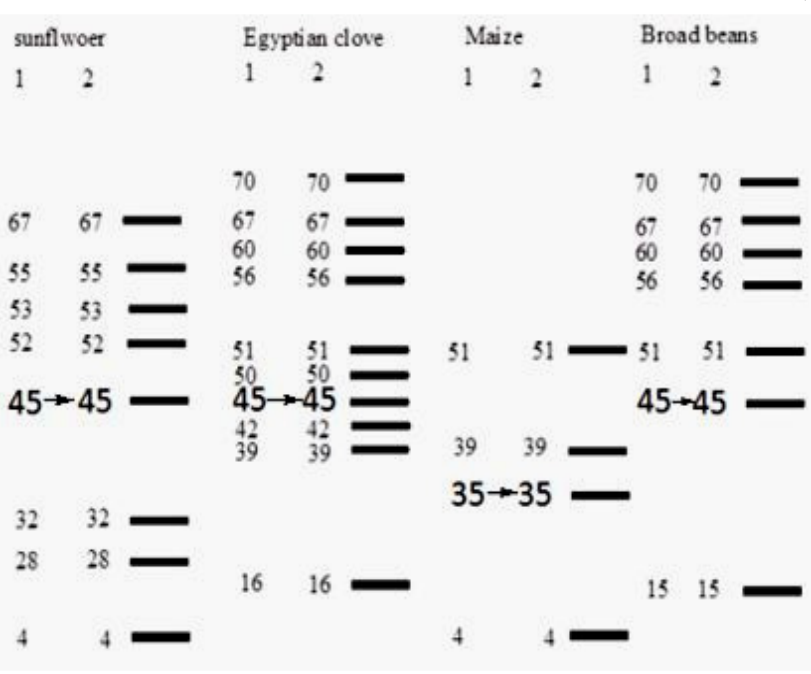

Fig. 2. Electrophoretic separation of albumin and globulin fractions of four pollen pellets: 1 - albumin; 2 - globulin

cytoplasmic. Three different extracts of Greek pollen have been tested in whether could induce proteasome activities in human fibroblasts. The water extract of pollen was found to induce a highly proteasome activity (Graikou $e t$ al., 2011) showing interesting antioxidant effect because of flavonoids and phenolic acids, which indicate the observed free radical scavenging activity (Carpes et al., 2009).

\section{Conclusion}

In order to have beneficial effects, honey must be free of any contaminating agents, such as heavy metals or pesticides above the admitted levels by pollution standards, and to be safe for human health. Bees, and their products, may be used as biological indicators of the environmental pollution existing in the area where they fly. Our investigations show appreciable differences between protein components of the four pollen pellets; this indicate that the environmental conditions have an important influence on pollen protein contents. The confirmation of these aspects would facilitate the preparation of an effective extract that could help improving the diagnostic precision of the allergenic protein subunits to pollen varieties, and could be useful for the preparation of cypress pollen allergen extracts intended for clinical applications.

\section{References}

Afify AEMMR (2010). Biological function of Xenobiotics through protein binding and transportation in living cells. Int J Agric Res 5:562-575.

Afify AEMMR, Shalaby EA, El-Beltagi HS (2011). Antioxidant activity of aqueous extracts of different caffeine products. Not Bot Horti Agrobo 39(2):117-123.

Afify AEMMR, Hossam SEB, Samiha MAES, Azza AO (2012). Biochemical changes in phenols, flavonoids, tannins, vitamin E, carotene and antioxidant activity during soaking of three white sorghum varieties. Asian Pacific Journal of Tropical Biomedicine 2(3):203-209. 
148

AOAC (2000). Official Methods of Analysis of the Association of Official Analytical Chemists, $17^{\text {th }}$ edn (edited by W. Horwitz). Washington, DC.

Afify AEMMR (2011). Pesticides in the Modern World Trends in Pesticides Analysis. Open access, ISBN 978-953-307-437-5. Edited by Stoytcheva M, Publisher: InTech.

Afify AEMMR, Mohamed MA, El-Gammal HA, Attalla ER (2010). Multiresidue method of analysis for determination of 150 pesticides in grapes using quick and easy method (QuEChERS) and LC-MS/MS determination. Food, Agriculture Environment 8(2):602-606.

Afify AMR, Ghali Y (1987). Effect of different methods of extraction on the protein of stored and fresh onion seed evaluated by polyacrylamide gel electrophoresis. Ann Agric Sci Moshto 25(1):267-275.

Almaraz-Abarca N, Campos MG, Ávila-Reyes JA, Jimenez NN, Corral JH, Gonzalez-Valdez LS (2007). Antioxidant activity of polyphenolic extract of monofloral honeybee-collected pollen from mesquite (Prosopis juliflora, Leguminosae). J Food Comp Anal 20(2):119-124.

AOAC (1975). Official methods of analysis of the association of official Agriculture chemists $12^{\text {th }} \mathrm{ed}$. Washington, DC.

Baroni MV, Chiabrando GA, Costa C, Wunderlin DA (2002). Assessment of the floral origin of honey by SDS-page immunoblot techniques. J Agri Food Chem 50(6):1362-1367.

Basim E, Basim H, Özcan M (2006). Antibacterial activities of Turkish pollen and propolis extracts against plant bacterial pathogens. J Food Engineer 77(4):992-996.

Bradford MM (1976). A rapid and sensitive method for the quantitation of microgram quantities of protein utilizing the principle of protein-dye binding. Analytical Biochemistry 72:248-254.

Carpes STGB, Mouraos MA, Masson ML (2009). Chemical composition and free radical scavenging activity of Apis mellifera bee pollen from Southern Brazil. Braz J Food Technol 12(3):220-229.

Celli G, Maccagnani B (2003). Honey bees as bio-indicators of environmental pollution. J Bull Insectology 56:137-139.

Dubois M, Gilles KA, Hamilton JK, Rebers PA, Smith F (1956). Colorimetric method for determination of sugars and related substances. Anal Chem 28:350-356.

Graikou K, Kapeta S, Aligiannis N, Sotiroudis G, Chondrogianni N, Gonos E, Chinou I (2011). Chemical analysis of Greek pollen-Antioxidant, antimicrobial and proteasome activation properties. Chem Central J 5:33.

Herbert EWJ (1992). Hony bees nutrition. In: "The hive and the hony bees", eds. Graham GM p:197-233 (Dadant and sons, Hamilton IL.)

Laemmli UK (1970). Cleavage of structural proteins during the assembly of the head of bacteriophage T4. Nature 227(5259):680-685.

Holden M (1965). Chlorophylls. In: Chemistry and biochemistry of plant pigments. Vol. 1. Ed. Hulme HC, Academic Press, p:305-68.
Hyde HA, Adams KF (1958). An Atlas of Airborne Pollen Grains, MacMillan \& Co. $\mathrm{L}^{\text {td }}$. New York, p. 112.

Nazarian H, Taghavizad R, Majd A (2010). Origin of honey proteins and method for its quality control. Pak J Bot 42(5):3221-3228.

Nieman RH, Poulsen LL (1962). Spectrophotometric Estimation of Nucleic Acid of Plant Leaves. Plant Physiol 1:31-35.

Mondal AK, Sanjukta M, Sudhendu M (2009). The free amino acids of pollen of some angiospermic taxa as taxonomic markers for phylogenetic interrelationships. Current Science 96(8):1071-1081.

Ogur M, Rosen G (1950).The nucleic acids of plant tissues; the extraction and estimation of desoxypentose nucleic acid and pentose nucleic acid. Arch Biochem 25(2):262-276.

Pfahler PF, Linskens HF (1970). Biochemical composition of maize pollen-I. Effects of endosperm mutants, waxy (Wx), shrunken (Sh.) and sugary $(\mathrm{Su})$ on amino acid content and fatty acid distribution. Theor Appl Genet 40:6-10.

Porter EK (1981). Origins and genetic nonvariability of the proteins which diffuse from maize pollen. Environm Health Perspectiv 37:53-59.

Rice-Evans CA, Miller NJ, Paganda G (1996). Structureantioxidant activity relationships of flavonoids and phenolic acids. Free Radical Biol Med 20:933-956.

Snedecor GW, Cochran WG (1956). Statistical methods applied to experiments in agriculture and biology. $5^{\text {th }} \mathrm{Ed}$. Ames Iowa State University Press, Iowa, p. 534.

Somerville DC, Nicol HI (2006). Crude protein and amino acid composition of honey bee collected pollen pellets from southeast Australia and a note on laboratory disparity. Australian J Experim Agri 46:141-149.

Stanciu OG, Marghitas LA, Dezmirean D, Campos MG (2011). A comparison between the mineral content of flower and honeybee collected pollen of selected plant origin (Helianthus annuus L. and Salix sp.). Romanian Biotechnol Letters 16(4):6291-6296.

Stanley RG, Linskens HF (1974). Pollen: biology, biochemistry, management. First Edition. Springer-Verlag, Heidelberg, Germany.

Sadasivam S, Manickam (1996). Biochemical Methods. New Age International (P) Limited Publ. Coimbatore and Tamil Nadu Agricultural University $2^{\text {nd }}$ edn.

Shahali Y, Majd A, Pourpak Z, Tajadod G, Haftlang M, Moin M (2007). Comparative study of the pollen protein contents in two major varieties of Cupressus arizonica planted in Tehran. Iran J Allergy Asthma Immunol 6(3):123-127.

Rubinelli P, Hu Y, Ma H (1998). Identification, sequence analysis and expression studies of novel anther-specific genes of Arabidopsis thaliana. Plant Mol Biol 37(4):607-619.

Urbach W, Rupp W, Sturm H. (1976). Experimente zur Stoffwech - Selphysiologieder Pflanzen. Georg Thieme Verlag, Stuttgart.

de Wreede I, Stegemann H (1981) Determination of proteins in the presence of large quantities of sodium-dodecyl-sulphate and mercapto-ethanol by a modifiedbiuret-method. Fresenius J Anal Chem 308(5):431-433. 